1986

\title{
To Have and To Hold: The Marital Rape Exemption and the Fourteenth Amendment
}

Anne Dailey

University of Connecticut School of Law

Follow this and additional works at: https://opencommons.uconn.edu/law_papers

Part of the Constitutional Law Commons, Criminal Law Commons, and the Law and Gender Commons

\section{Recommended Citation}

Dailey, Anne, "To Have and To Hold: The Marital Rape Exemption and the Fourteenth Amendment" (1986). Faculty Articles and Papers. 389.

https://opencommons.uconn.edu/law_papers/389 


\section{HEINONLINE}

Citation:

To Have and to Hold: The Marital Rape Exemption and the Fourteenth Amendment, 99 Harv. L. Rev. 1255 (1986)

Content downloaded/printed from $\underline{\text { HeinOnline }}$

Wed Oct 31 17:02:06 2018

-- Your use of this HeinOnline PDF indicates your acceptance of HeinOnline's Terms and Conditions of the license agreement available at https://heinonline.org/HOL/License

-- The search text of this PDF is generated from uncorrected OCR text.

-- To obtain permission to use this article beyond the scope of your HeinOnline license, please use:

\section{Copyright Information}

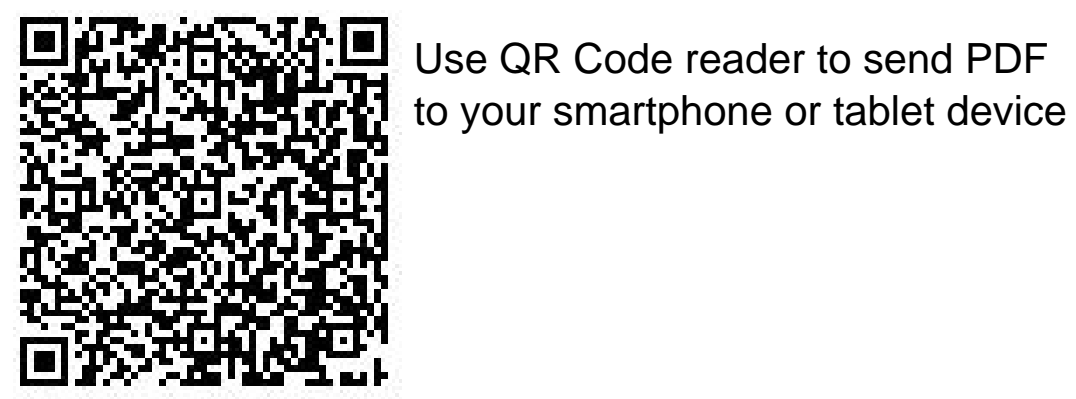




\section{To Have and to Hold: The Marital Rape Exemption and THE FOURTEENTH AMENDMENT}

The study of inequality "should be concerned with power at its extremities, in its ultimate destinations, with those points where it becomes capillary."1 A husband's violent sexual possession of his wife against her will is such a point of power. And the law's sanctioning of this exercise of power transforms this power into truth. Therefore, when men say "a husband cannot rape his wife," they speak the truth. When women accuse their husbands of rape, they lie. Because women are perceived to be liars, they remain silent. ${ }^{2}$ The dominant discourse of truth thus evolves from the reality of ongoing subjugation. ${ }^{3}$

The aim of this Note is to help give women the power to speak a different truth, to help women gain "the status of those who are charged with saying what counts as true." 4 Part of their truth is that the marital rape exemption serves as both a manifestation of and a vehicle for the continued subordination of women in society. ${ }^{5}$ Part I of this Note begins with the history of the marital rape exemption and a critique of the theories that have served to justify it. In light of this history, Part I then examines the experience of marital rape victims and the rape laws that regulate that experience. Part $I I$ argues that the marital rape exemption impermissibly infringes married women's rights to privacy and unconstitutionally conditions all women's rights to marry and to privacy. Part II then examines the limitations of adopting a rights-based approach as part of a broader strategy for gender equality. Finally, Part III argues that the marital rape exemption discriminates against all women in violation of the equal protection guarantee of the fourteenth amendment.

\section{The Marital Rape Exemption}

\section{A. Common Law History and Statutory Developments}

The marital rape exemption originated at common law in the seventeenth century with Lord Matthew Hale's declaration that "the

1 M. Foucault, Two Lectures, in Power/KNowledge 78, 96 (C. Gordon ed. 1980).

${ }^{2}$ Cf. C. Gilligan, IN A Different VoICE I73 (1982) (noting that "we have come more recently to notice not only the silence of women but the difficulty in hearing what they say when they speak").

${ }^{3}$ See M. Foucault, supra note 1 , at 78, 97; MacKinnon, Feminism, Marxism, Method, and the State: Toward Feminist Jurisprudence, 8 SigNs: J. WOMEN IN CULTURE \& SOc'Y 635 , 640 (1983) ("Feminism distinctively as such comprehends that what counts as truth is produced in the interest of those with power to shape reality . . . .").

${ }_{4}^{4}$ M. Foucault, Truth and Power, in Power/KNowledge I09, 13I (C. Gordon ed. I980).

5 Professor Karst has noted that the "process by which law confers legitimacy on a structure of domination and dependency is primarily a system of symbols. For a court to add the judiciary's own special imprimatur of legitimacy on the symbolism of women's dependency is particularly destructive." Karst, "A Discrimination so Trivial": A Note on Law and the Sym- 
husband cannot be guilty of a rape committed by himself upon his lawful wife, for by their mutual matrimonial consent and contract the wife hath given up herself in this kind unto her husband, which she cannot retract." Hale has long stood as the accepted authority on marital rape in the United States. ${ }^{7}$ Although this "implied consent" theory has been the most commonly invoked justification, two other theories - the "unities" theory and the theory of separate spheres have also served to justify the marital rape exemption. This Section traces the history of the unities and separate spheres theories as they have developed in the context of marital rape.

The unities theory derived from the feudal doctrine of coverture, or unity of husband and wife. ${ }^{8}$ Blackstone articulated this unities doctrine in his Commentaries: "By marriage, the husband and wife are one person in law: that is, the very being or legal existence of the woman is suspended during the marriage, or at least is incorporated and consolidated [into her husband]." 9 Although the unities doctrine posited that the husband and wife became one upon marriage, in reality "the one [was] the husband." 10 The unities doctrine thus served to legitimate the propertization of women through marriage. Wives were viewed as their husbands' chattel, deprived of all civil identity. ${ }^{11}$

Because women were property, the common law treated rape not as a violation of women, but "as a property crime of man against man."12 Most notably, the law protected a father's interest in his daughter's virginity and a husband's interest in his wife's fidelity. ${ }^{13}$

bolism of Women's Dependency, 35 OHIo ST. L.J. 546, $55^{2}$ (1974) (citations omitted) (emphasis in original).

6 i M. Hale, The History of the Pleas of the Crown 629 (S. Emlyn ed. 1778); see Note, The Marital Rape Exemption, 52 N.Y.U. L. REV. 306, 307 (1977) (noting that Hale's statement was the basis for judicial recognition of the marital rape exemption in the United States).

${ }^{7} \mathrm{See}$, e.g., Commonwealth v. Fogarty, 74 Mass. (8 Gray) 489,490 (1857) (citing Hale in support of the exemption); Note, supra note 6 , at 307 n.I3.

${ }^{8}$ See Clancy, Equal Protection Considerations of the Spousal Sexual Assault Exclusion, 16 NEW ENG. L. REV. I, I7 (Ig80).

9 I W. Blackstone, CoMmentaRIES * 442.

10 United States v. Yazell, 382 U.S. 34I, 36I (I966) (Black, J., dissenting).

11 Before the passage of the Married Women's Property Acts, a married woman was unable to sue or be sued, enter into contracts, make wills, retain her own earnings, or manage her own property. See L. Kanowitz, Women and the LaW: The UNFinished Revolution 3538 (I969); cf. Williams, The Equality Crisis: Reflections on Culture, Courts and Feminism, 7 WOMEN's RTS. L. REP. I75, I77 (1982) (noting that a husband had the right to chastise his wife, restrain her freedom, and impose sexual intercourse upon her against her will).

12 S. Brownmilleg, Against Our Will 8 (I975); see R. TONg, Women, SeX, and the LAW go (1984).

13 See People v. Liberta, 64 N.Y.2d I52, 167-68, 474 N.E.2d 567, 576 (I984) (noting that "the purpose behind [early rape laws] was to protect the chastity of women and thus their property value to their fathers or husbands"), cert. denied, ro5 S. Ct. 2029 (1985); R. ToNG, supra note 12, at 92 ("The rapist either robs the father of his daughter's virginity before this valuable 'commodity' reaches the matrimonial market, or he robs the husband of certitude with 
Rape of an unmarried woman rendered her unmarriageable because her value to future husbands was destroyed, ${ }^{14}$ while rape of a married woman brought disgrace upon her husband and family. Men's acquisition of women as property was thus regulated by laws on rape. Against this background of laws prohibiting rape outside of marriage worked a social practice encouraging rape both within and prior to marriage. The English customs of "bride capture," whereby a man staked his claim to a woman through rape, and "stealing an heiress," whereby a man kidnapped a woman into marriage, were ways for men to acquire valuable property and social status. ${ }^{15}$ The law on marital rape served to complete the conceptual framework by establishing a man's sexual entitlement to a woman within the marriage contract. The marital rape exemption thus reinforced social practice, sanctioning female sexual subordination as a weapon in the struggle for power among men.

Women's legal status began to change with the passage of the Married Women's Property Acts in virtually every state during the second half of the nineteenth century. ${ }^{16}$ Yet these reforms, although altering the status of women in the legal and economic spheres, were not conceived in the spirit of equal rights. Rather, the Acts reflected the development of a "separate spheres" ideology, which gradually displaced the unities theory as the legal justification for sexual inequality. ${ }^{17}$ Under this vision of social relations, men inhabit the public realm of politics and the marketplace and women inhabit the private realm of the family. Women were no longer naturally inferior, but naturally different. ${ }^{18}$ They were free to fulfill "the noble and benign

respect to the fatherhood of his progeny, in addition to damaging or stigmatizing his prized possession.").

14 See Note, supra note 6, at $309 \mathrm{n.22}$; see also Comment, Rape and Battery Between Husband and Wife, 6 STAN. L. REv. 7I9, 724 (1954) ("At least historically, [rape] has had great importance in destroying the acceptability of an unmarried girl as a bride." (footnote omitted)). Freud wrote that "[t]he demand that the girl shall bring with her into marriage with one man no memory of sexual relations with another is after all nothing but a logical consequence of the exclusive right of possession over a woman which is the essence of monogamy." S. Freud, Contributions to the Psychology of Love, in 4 Collected PAPERS 217 (J. Riviere trans. 1959).

${ }_{15}$ See S. BRowNMILLER, supra note 12 , at 7, 15. At common law, a victim could save her rapist from the death penalty through marriage. See id. at I6.

${ }_{16}$ Mississippi passed the first Married Women's Property Act in 1839 , and within fifty years every American jurisdiction had adopted some form of the Act. See L. KaNowitz, supra note II, at 40-4I. These Acts sought to reform the common law status of married women by granting them the right to contract, to sue and be sued, to manage and control their own property, to work outside the home without the permission of their husbands, and to retain the earnings derived from their employment. See id. at 40.

17 See Williams, supra note II, at 177-78.

18 See Muller v. Oregon, 208 U.S. 4I2, 42I-23 (Ig08); see also Law, Rethinking Sex and the Constitution, 132 U. PA. L. REv. 955, 958 (1984) ("Assumptions about biological difference and destiny provided the prime justification for creating a separate, inferior legal status for women." (footnotes omitted)). 
offices of wife and mother."19 As Justice Bradley stated in 1872 , "the civil law, as well as nature herself, has always recognized a wide difference in the respective spheres and destinies of man and woman." 20 The separate spheres ideology helped shape the notion that any legal intrusion upon the woman's sphere constituted an illegitimate public invasion of the private sphere. The private subordination of women was therefore accomplished by the absence of laws restraining male power. ${ }^{21}$ In this unregulated private sphere, men were free to oppress women. Specifically, they were free to rape their wives.

The last Ioo years have witnessed significant changes in the legal and social status of women. The nineteenth amendment, 22 title VII of the Civil Rights Act of $1964,{ }^{23}$ and the I97 I case Reed v. Reed ${ }^{24}$ represent legal signposts on the road to full disintegration of the separate spheres ideology. The vitality of the marital rape exemption, however, testifies to the continuing influence of this ideology on the formation of legal doctrine. The contemporary rationales for the marital rape exemption exhibit an underlying adherence to the notions of female inferiority and female difference. Although legislators and judges do not explicitly refer to women as chattel or to women's natural role in the home, ${ }^{25}$ the rationales for the marital rape exemption, discussed below, ${ }^{26}$ betray deep, perhaps unconscious, discriminatory views.

\section{B. Current Legal Protection of Marital Rape}

At least fourteen percent of married women are raped by their husbands, ${ }^{27}$ yet only ten states expressly allow prosecution of these

${ }^{19}$ Bradwell v. Illinois, 83 U.S. (I6 Wall.) I30, I4I (I872) (Bradley, J., concurring).

$20 \mathrm{Id}$.

${ }^{21}$ See Taub \& Schneider, Perspectives on Women's Subordination and the Role of Law, in THE POLITICS OF LAW II7, I22 (D. Kairys ed. 1982) ("Isolating women in a sphere divorced from the legal order contributes directly to their inferior status by denying them the legal relief that they seek to improve their situations and by sanctioning conduct of the men who control their lives.").

${ }^{22}$ U.S. CoNST. amend. XIX ("The right of citizens of the United States to vote shall not be denied or abridged by the United States or by any State on account of sex.").

${ }^{23} 42$ U.S.C. $\$ 2000$ ( 1982$)$. Title VII prohibits discrimination on the basis of sex by any employer of fifteen or more persons engaged in an industry affecting commerce.

${ }_{24} 404$ U.S. 7I (197I). In Reed, the Supreme Court departed from its traditional rational relation standard of review with respect to gender-based classifications and established the foundation for the intermediate level of review developed in subsequent decisions. See Mississippi Univ. for Women v. Hogan, $45^{8}$ U.S. 718, 723-24 (1982).

${ }^{25}$ See, e.g., Trammel v. United States, 445 U.S. 40, 52 (I980) ("Nowhere . . is a woman regarded as chattel or demeaned by denial of a separate legal identity and the dignity associated with recognition as a whole human being.").

${ }^{26}$ See infra pp. 1268-69.

${ }^{27}$ D. RuSSELL, RAPE IN MARRIAGE 57 (I982). Russell's survey defined rape as forced oral, anal, or vaginal penetration. See id. at 43 . 
men under all circumstances. ${ }^{28}$ State rape statutes thwart prosecution for marital rape in various ways. Traditionally, rape has been defined as nonconsensual sexual intercourse by a man with a female, not his wife. ${ }^{29}$ Some states explicitly incorporate a marital rape exemption by defining rape in this manner, ${ }^{30}$ while other states refer simply to intercourse with a female or person and then define that term to exclude the wife or spouse of the actor. ${ }^{31}$

In the states with marital rape exemptions, the scope of the exemption depends upon the perceived stability of the underlying marriage. States generally regulate the scope of the exemption through the definition of "not married" under the statute. For example, some states define "not married" so as to allow prosecution if the parties were living apart at the time of the incident. ${ }^{32}$ Other states allow prosecution only if the parties at the time of the incident were separated by court order ${ }^{33}$ or were living apart and one spouse had filed a petition for annulment, divorce, separation, or separate maintenance. ${ }^{34}$ In Alabama, Illinois, and South Dakota, a husband is sub-

${ }^{28}$ Eight state legislatures have rejected the marital rape exemption. See Fla. Stat. ANN. \$ 794.0II (West Supp. 1985); Kan. Stat. ANN. \$ 21-3502 (Supp. 1984); Mass. Gen. LawS ANN. ch. 265, § 22 (West Supp. 1985); NEB. REv. Stat. $\$ \$ 28-319,-320$ (I979); N.J. STAt. ANN. \$ 2C:I4-5(b) (West I982); OR. REv. STAT. \$\$ I63.355-.375 (I985); VT. STAT. ANN. tit. I3, § 3252 (Supp. 1985); WIS. STAt. ANN. \$ 940.225(6) (West Supp. 1985). New York has removed its marital rape exemption through judicial action. See People v. Liberta, 64 N.Y.2d 152, 474 N.E.2d 567 (1984), cert. denied, 105 S. Ct. 2029 (I985). The Georgia judiciary has held that its rape statute, which is silent on marital rape, does not implicitly incorporate the common law exemption. See Warren v. State, 225 Ga. 15I, 336 S.E.2d 221 (Ig85).

Several states allow prosecution of husbands for charges of first or second-degree rape, but disallow prosecution for lesser sexual offenses. See, e.g., CAI. PENAL Code $\$$ 26I-262 (West Supp. 1986); Conn. Gen. Stat, ANN. \$\$ 53a-67(b), -70(b) (West Supp. 1985); Del. Code ANN. tit. II, $\$$ 76I-763 (I979); IOWA CODE ANN. \$\$ 709.2-.4 (West 1979); I8 PA. CoNs. Stat. ANN. \$ 3128 (Purdon Supp. I985); WASH. REv. CODE ANN. \$ 9A.44.040, -.050, -.06o(I) (West Supp. I986); W. VA. Code \$ 6I-8B-6 (I984); Wyo. STAT. \& 6-2-307 (I977).

${ }^{29}$ See, e.g., Act of July 26 , I88I, ch. $676, \$ 278$, I88I N.Y. Laws 67 (Vol. III).

30 See, e.g., UTAH Code ANN. \$ 76-5-402 (1978 \& Supp. I985).

31 See, e.g., ALA. CODE § I3A-6-60(4) (1977).

32 See, e.g., ARIz. Rev. STAT. ANN. \$§ I3-I40r.4, -I407(D) (Supp. I985); Colo. Rev. Stat. $\S$ I8-3-409(2) (1978); ME. REv. Stat. ANN. tit. I7A, §§ 25I.I.A, 252.1.A (I983); Miss. Code ANN. § 97-3-99 (Supp. I985); MONT. CODE ANN. § 45-5-5II(2) (1985).

33 See, e.g., Ky. Rev. Stat. \$ 5 I0.010(3) (I985); LA. REV. Stat. ANN. § I4.4I (West I974 \& Supp. I985); MD. ANN. CODE art. 27, § 464D (I982); Mo. ANN. STAT. $\$ 566.010 .2$ (Vernon I979); N.C. GeN. STAT. § I4-27.8 (198I); N.D. CENT. CODE § I2.I-20-OI.2 (I985); R.I. GeN. LAwS $\$ \S$ Ir-37-I, -2 (I98I \& Supp. I985); S.C. CoDE ANN. \& 16-3-658 (Law Co-op. 1985); UTAH CODE ANN. $\$ \$ 76-5-402,-407$ (I978 \& Supp. 1985).

34 See, e.g., IND. CODE ANN. \$ 35-42-4-I-(b) (Burns I985); Nev. Rev. Stat. \$ 200.373 (I985); Ohio Rev. Code AnN. \& 2907.0I(L) (Page I982); Tenn. Code AnN. § 39-2-6ro (I982). Four states allow prosecution if the spouses were living apart or one spouse had initiated divorce proceedings at the time of the incident. See IDAfo CODE § I8-6107 (1979); N.M. STAT. ANN. \$ 30-9-Io (1978); Okza. Stat. ANn. tit. 2 I, § IIII(B) (West Supp. I985); Tex. Penal Code ANN. \$ 22.0II(c)(2) (Vernon Supp. 1986). 
ject to prosecution for rape only if a final divorce decree existed at the time of the incident; a wife separated from her husband under agreement or court decree has no legal recourse. ${ }^{35}$

The exemption purports to protect the harmonious and intimate nature of the marital relationship. ${ }^{36}$ The detailed statutory definitions of "not married" reflect an attempt on the part of states to limit the exemption to marriages that conform to this ideal. Yet nearly onequarter of the states have recently expanded the marital rape exemption to cover unmarried cohabitators ${ }^{37}$ and "voluntary social companions." 38 This expansion of the exemption beyond the traditional boundaries of legal marriage cannot be justified as serving the exemption's primary rationale - the preservation of marital privacy and harmony. Instead, the expansion of the exemption beyond the marital relationship reflects the deeply discriminatory vision of women inherent in the theories used to justify the exemption; in particular, the expansion reflects a modern version of Hale's theory that women who enter into relationships with men give an implied consent to sexual intercourse or that those who consent to intercourse once are forever bound.

The vision that women impliedly consent to rape constitutes one side in the legal debate over the marital rape exemption - a debate that centers on the interpretation of a husband's unconsented-to sexual intercourse with his wife. One interpretation, which this Note terms the "male perspective," 39 sees marital rape as "a bedroom squabble over whether to have sex tonight." 40 A "female perspective," on the

35 See AlA. Code $\S$ 13A-6-6o to -6I (1982); ILl. Rev. STAT. ch. 38, § I2-I8(c) (Supp. I983); S.D. COMP. LAWS ANN. $\$ 22-22-1$ (I979).

36 See infra p. 1268.

37 See, e.g., Ala. Code § 13A-6-60(4) (1977); Conn. Gen. Stat. § 53a-67(b) (1985); Del. CODE ANN. tit. II, § 764(2) (I979); HAWAII REV. STAT. § 707-730(I)(a)(i) (Supp. I984); IowA CODE ANN. \& 709.4 (I979); Ky. REv. STAT. § 510.oro(3) (I985); ME. REV. STAT. ANN. tit. I7A, § 252(3) (Supp. I985); Mont. Code ANN. § 45-5-51 I(2) (r985); Pa. Stat. AnN. tit. I8, § 3103 (Purdon Supp. I985); W. VA. CODE § 6I-8B-I(2) (I984).

38 See, e.g., Del. CODE ANN. tit. II, § 764(2) (I979): HawaII Rev. Stat. § 707-730(I)(a)(i) (Supp. I984); ME. Rev. STAT. ANN. tit. I7A, \$ 252(3) (Supp. I985).

39 Although this Note terms these perspectives "male" and "female," the terminology is not meant to suggest that they necessarily correspond to men and women. For a discussion of how the law of rape in general reflects a male perspective, see Estrich, Rape, 95 YALE L.J. (forthcoming I986).

40 D. Finkelhor, Marital Rape: The Misunderstood Crime, Address to the New York County Lawyer's Association (May 3, I984) (describing the views of those who hold a male perspective on marital rape); see Hilf, Marital Privacy and Spousal Rape, I6 NEW ENG. L. REv. 3I, 34 ( 1980 ) (arguing in support of the marital rape exemption because "there is good sense in not permitting every marital scuffle to become a case for the courts"); $c f$. Comment, Forcible and Statutory Rape: An Exploration of the Operation and Objectives of the Consent Standard, 62 YALE L.J. 55, 67 (I952) (stating that "a woman's need for sexual satisfaction may lead to the unconscious desire for forceful penetration"). 
other hand, interprets marital rape as involving "brutality and terror and violence and humiliation to rival the most graphic stranger rape." 41 The female voice can be heard in the stories told by marital rape victims ${ }^{42}$ and in the judicial opinions that invalidate or reject the exemption. ${ }^{43}$ Arguments for and against the exemption assume more subtle guises, but ultimately the positions divide at this fundamental point of interpretation.

The male perspective accepts the myth that marital rape has no traumatic long-term effects. ${ }^{44}$ The female perspective recognizes facts to the contrary. Victims of marital rape experience a trauma similar to that of victims of stranger rape. Rape by anybody, including a husband, "is a degrading, violent act which violates the bodily integrity of the victim and frequently causes severe, long-lasting physical and psychic harm." 45 In fact, "[m]arital rape is frequently quite violent and generally has more severe, traumatic effects on the victim than other rape." 46 Stranger rape is a devastating one-time occurrence; marital rape frequently involves a series of devastating occurrences, often spanning years. ${ }^{47}$ Marital rape victims often suffer from a debilitating psychological dependency that ties them to their abusive husbands. Frequently these wives are also battered. ${ }^{48}$ One study

The male perspective takes the following form: "The way I see it, Cathy and I were having problems in our marriage for the last two years. She could have claimed "rape" any time during that time. Half of the married men in the country are guilty of the same thing if that's rape."

D. RUSSELL, supra note 27 , at 19 (quoting a husband convicted of marital rape).

$41 \mathrm{D}$. Finkelhor, supra note 40.

42 "Our marriage really deteriorated after [I was raped by a stranger]. It was the end of my pedestal days. He approached me sexually when I was still very injured, and I said, 'No, please don't. Not now . . . .' His reaction was, ' $I$ have rights, and you're my wife, and as long as you're my wife, it is my conjugal right. So don't fight me.' . . When I saw that he was determined to go ahead, I really couldn't believe it, and I started crying. He proceeded, and when he was finished he left the room and slammed the door."

D. RUSSELL, supra note 27 , at 169 (quoting a marital rape victim).

43 See, e.g., People v. Liberta, 64 N.Y.2d 152, I64, 474 N.E.2d 567, 573 (1984) (noting that "[a] married woman has the same right to control her body as does an unmarried woman"), cert. denied, ro5 S. Ct. 2029 (I985); State v. Smith, 85 N.J. I93, 2ro-I I, 426 A.2d 38, 47 (198I) (stating that New Jersey's marital rape exemption "treats [women] as the sexual property of their husbands").

44 The Model Penal Code adheres to this myth: "The character of the voluntary association of husband and wife . . . may be thought to affect the nature of the harm involved in unwanted intercourse." MODEL PENAL CODE § 213 .I, comment 8(c), at 346 (Ig85).

45 Liberta, 64 N.Y.2d at 164,474 N.E.2d at 573 (citations omitted).

46 Id.; see D. RUSSELL, supra note 27 , at 190-205.

47 Thirty-one percent of the participants in a study of marital rape victims conducted by Diane Russell had been raped once by their husbands; $37 \%$ had been raped from 2-20 times; and $3 \mathrm{r} \%$ had been raped over 20 times. See D. RUSSELL, supra note 27 , at III.

4s See id. at go (noting that ten percent of married women experience both wife rape and wife beating). 
found that fifty-two percent of the victims of marital rape suffer severe long-term effects ${ }^{49}$ as compared to thirty-nine percent of the victims of stranger rape. ${ }^{50}$ These statistics reflect the fact that "[w]hen you are raped by your husband you [have to] live with your rapist." 51

\section{The Rights APPROACH}

Part II focuses on a rights-based argument as a means both for challenging the constitutionality of the marital rape exemption and for achieving gender equality. Section A presents two arguments, both of which perceive the marital rape exemption in terms of the violation of women's individual rights. Subsection I argues that the marital rape exemption impermissibly infringes the privacy rights of married women. Subsection 2 argues that the exemption unconstitutionally burdens the privacy rights of all women.

Section B takes a broader political perspective and argues that a rights-based approach, although a powerful one to take in court, is limited by its conceptual framework of individual, abstract rights. This Section argues that because the rights approach focuses on the rights of individual women, it fails to identify marital rape as part of the broader problem of women's subordination.

\section{A. Women's Right to Privacy}

r. Privacy Rights of Married Women. - Although the Constitution does not explicitly guarantee a right to privacy, the Supreme Court has established the constitutional status of this right in such cases as Griswold v. Connecticut, ${ }^{52}$ Eisenstadt v. Baird,,$^{53}$ and Roe v. Wade. ${ }^{54}$ The Court has declined to locate the right to privacy in any specific constitutional provision, but rather has held that the right inheres in the first, fourth, fifth, and ninth amendments, the penumbra of the Bill of Rights, and in the concept of liberty guaranteed by the fourteenth amendment. ${ }^{55}$ In Eisenstadt, the Court refined the contours of personal privacy to mean "the right of the individual ... to be

${ }^{49} \mathrm{See} i d$. at $192-93$. These long-term effects include increased negative feelings toward oneself (18\%) and increased negative feelings toward men (37\%). See id.

50 See id. at 192.

51 D. Finkelhor, supra note 40; see Yllo \& Finkelhor, Marital Rape, in RAPE AND SEXUAL Assault I54 (A. Burgess ed. I985).

5238 I U.S. $479,485-86$ (I 965 ) (holding that the right of privacy protects married persons' access to contraception).

${ }^{53} 405$ U.S. 438,453 (1972) (holding that the right of privacy protects all persons' access to contraception).

${ }^{54} 410$ U.S. I13, I52 (1973) (holding that the right of privacy protects a woman's decision to terminate her pregnancy).

${ }^{55}$ See, e.g., Roe, 4 10 U.S. at $152 ;$ Griswold, 38 I U.S. at $484-85$. 
free from unwarranted governmental intrusion into matters so fundamentally affecting a person as the decision whether to bear or beget a child." $" 56$

The right to privacy has been held to protect bodily integrity, ${ }^{57}$ reproductive freedom, ${ }^{58}$ and individual autonomy. ${ }^{59}$ The marital rape exemption allows a husband to violate his wife's bodily integrity. It allows him to impregnate her against her will in denial of her reproductive freedom. And perhaps most important, the exemption extinguishes a married woman's autonomy in one of the most personal and intimate of all human interactions. The state thus violates the privacy rights of married women by allowing their husbands to rape them without fear of prosecution. ${ }^{60}$

State laws that interfere with the right to privacy in this way must be narrowly tailored to further a compelling state interest. ${ }^{61}$ Very rarely will a court deem state interests sufficiently compelling to overcome the standard's implicit presumption of unconstitutionality. ${ }^{62}$ The state interests behind the marital rape exemption include respecting marital privacy, encouraging the reconciliation of spouses, and obviating the evidentiary problem of proving lack of consent in marital rape claims. As this Note demonstrates in Part III, these interests

56 Eisenstadt, 405 U.S. at 453 (emphasis in original).

57 See Winston v. Lee, I05 S. Ct. I6II, I6I8-19 (1985) (holding that individual privacy interests, including the right to bodily integrity, render compulsory surgery in search of criminal evidence unconstitutional); $c f$. Union Pac. R. Co. v. Botsford, I4I U.S. 250, 25 I (I89I) ("No right is held more sacred ... than the right of every individual to the possession and control of his own person....").

58 See Eisenstadt v. Baird, 405 U.S. 438,453 (1972) (holding that the decision whether to have a child is a fundamental element of the right of privacy).

${ }^{59}$ See Whalen v. Roe, 429 U.S. 589, 599-600 (1977) (holding that the right to privacy protects "the interest in independence in making certain kinds of important decisions").

60 The fourteenth amendment proscribes only certain state actions and has never been extended to govern the actions of private individuals. Thus, the amendment does not proscribe marital rape as such. But the amendment does govern state actions taken to regulate rape and other criminal conduct. And a deliberate legislative or judicial choice to carve exceptions out of the criminal code - such as the marital rape exemption - must also constitute state action for purposes of fourteenth amendment analysis. Cf. Reitman v. Mulkey, 387 U.S. 369, 38I (I967) (holding that a state constitutional amendment securing to private property holders the right to dispose freely of their property was sufficient state action); Shelley v. Kraemer, 334 U.S. I, I8-I9 (I948) (holding that state judicial enforcement of a private, racially restrictive covenant was sufficient state action). Professor Tribe has noted that "if the conception of liberty is sufficiently developed to define a sphere of private autonomy free from both governmental and private infringement, a government decision not to protect individuals from private infringements will plainly be a species of unconstitutional state action." L. TrIBE, AMERICAN Constitutionaz LAW § I8-2, at II50 (I978).

61 See Roe v. Wade, 410 U.S. II3, 155 (1973).

62 See Gunther, The Supreme Court, 1971 Term - Foreword: In Search of Evolving Doctrine on a Changing Court: A Model for a Newer Equal Protection, 86 HARV. L. REV. I, 8 (1972) (noting that strict scrutiny is "strict' in theory and 'fatal' in fact"). . 
fail to withstand intermediate scrutiny. ${ }^{63}$ They therefore fall far short of satisfying a strict standard of judicial review.

2. Privacy Rights of All Women. - A second challenge to the marital rape exemption argues that the exemption unconstitutionally burdens the privacy rights of all women. Specifically, the marital rape exemption falls within the doctrine of "unconstitutional conditions," which holds that a state may not condition the receipt of government benefits upon the nonassertion of a constitutional right.64 Although the Supreme Court has been most willing to recognize the doctrine of unconstitutional conditions in the areas of speech and religion, ${ }^{65}$ it has indicated its willingness to apply the doctrine when other constitutional rights, such as the right to privacy, are at stake. ${ }^{66}$ Moreover, such an application comports with the constitutional recognition that certain rights are fundamental and thus are beyond the reach of governmental interference.

The marital rape exemption unconstitutionally conditions women's receipt of government benefits in two distinct ways. First, the exemption conditions the benefit of marriage upon women's forfeiture of their rights to bodily integrity, procreative freedom, and individual autonomy. Second, the exemption works in reverse by conditioning the benefit of protection from rape upon women's forfeiture of their fundamental right to marry. ${ }^{67}$ Thus, the exemption forces all women to surrender either their right to marry or their right to privacy.

When a statute has been shown to condition the receipt of a government benefit upon the surrender of a constitutional right, courts

${ }^{63}$ See infra pp. 1268-69. The New York Court of Appeals has held that these interests fail to withstand even minimal scrutiny. See People v. Liberta, 64 N.Y.2d r52, I64, 474 N.E.2d 567,573 (1984) ("[T]here is no rational basis for distinguishing between marital rape and nonmarital rape.") The defendant in Liberta, considered "unmarried" for purposes of the statute, was convicted of forcibly raping and sodomizing his wife in the presence of their two-year-old son. The defendant claimed that the state's rape statute violated the equal protection clause because it discriminated against "unmarried" men. The New York Court of Appeals agreed, striking down the exemption as unconstitutional. See id.

${ }^{64}$ See Note, Unconstitutional Conditions, 73 HARV. L. REv. 1595 (I960); see also Sherbert v. Verner, 374 U.S. $398,404-06$ ( I $_{93}$ ) (holding that the government may not condition the receipt of unemployment compensation upon the abandonment of a religious precept).

${ }^{65}$ See, e.g., Mt. Healthy Bd. of Educ. v. Doyle, 429 U.S. 274, 284 (1977); Pickering v. Board of Educ., 39I U.S. 563,568 (1968); Sherbert, 374 U.S. at 406.

${ }^{66}$ See Harris v. McRae, 448 U.S. 297 (I980). In Harris the Court noted that "[a] substantial constitutional question would arise if Congress had attempted to withhold all Medicaid benefits from an otherwise eligible candidate simply because that candidate had exercised her constitutionally protected freedom to terminate her pregnancy by abortion." Id. at 317 n.rg. But see The Supreme Court, 1983 Term - Leading Cases, 98 HARv. L. REv. 87,87 n.3 (I985) (arguing that Harris reflected a movement back toward the notion that the government has the unfettered right to attach conditions to entitlements).

67 See Zablocki v. Redhail, 434 U.S. 374, 383 (1978) (holding that the freedom to marry is a fundamental right under the Constitution). 
apply strict scrutiny. 68 As noted in Subsection I above, the rationales for the marital rape exemption fail to withstand even intermediate scrutiny, and thus certainly cannot survive a strict standard of judicial review.

\section{B. Limitations of a Rights Approach as a Strategy for Gender Equality}

A rights approach provides a powerful argument against the marital rape exemption and could render the exemption invalid. Yet a husband's legal immunity is only part of the broader problem of women's subordination. Because a rights approach has several important limitations that undermine its ability to confront the underlying issue of power distribution between men and women in our society, it may not be the wisest legal avenue by which to challenge the marital rape exemption.

In the sphere of sexuality, as elsewhere, a liberal view of rightsbased social relations leads to a theoretical stalemate between the values of security and freedom. ${ }^{69}$ In the context of marital rape, for example, a woman's right to bodily integrity (individual security) confronts a man's right to marital privacy (freedom from state intrusion). In principle, the man's right of marital privacy is no less fundamental than the woman's right to bodily integrity, and the rights approach as such offers no objective, apolitical basis upon which to decide between these competing rights. ${ }^{70}$ Liberal theory cannot adequately justify why one right should prevail over another, because any hierarchy of values must derive from some source external to the neutral liberal universe. ${ }^{71}$ By bracketing out the political sphere, rights anal-

${ }^{68}$ See Sherbert v. Verner, 374 U.S. 388,405 (I963).

${ }^{69}$ See Olsen, Statutory Rape: A Feminist Critique of Rights Analysis, 63 TEx. L. REv. 387 , $389-90(1984)$. As Olsen points out, "not all exercises of freedom undermine the security of others, but most of the exercises of freedom that people seek to restrict do threaten someone else's security. Similarly, most efforts by the state to protect the security of one person or group interfere with the freedom of another." Id. at 387 n.I. For example, laws regulating abortion can be viewed as undermining the security of the fetus or the freedom of the woman; laws regulating pornography can be viewed as undermining the security of women or the freedom of pornographers; and laws regulating statutory rape can be viewed as undermining both the security and the freedom of young women.

70 See Kennedy, The Structure of Blackstone's Commentaries, 28 Buffalo L. Rev. 205, 2I I-I3 (I979); Olsen, supra note 69, at 387-90; Dalton, Book Review, 6 HARV. WOMEN's L.J. 229,235 ( 1983 ). This theoretical stalemate surfaces in areas where a clear "consensus" as to the resolution of conflicting rights does not exist, as in the context of abortion. "The interests of the mother and the fetus are opposed. On which side should the State throw its weight? The issue is volatile; and it is resolved by the moral code which an individual has." United States v. Vuitch, 402 U.S. 62, 80 (197I) (Douglas, J., dissenting in part).

${ }^{1}$ Cf., e.g., Planned Parenthood v. Danforth, 428 U.S. 52, 7I (I976) ("Inasmuch as it is the woman who ... is the more directly and immediately affected by the pregnancy, as between [the wife and the husband], the balance weighs in her favor."); R. POSNER, Economic ANalysis 
ysis ignores the only true ground of decision in this context: the reality of women's sexual subordination to men.

In addition, applying rights analysis to issues of equality between the sexes forces women into seemingly contradictory positions, arguing for freedom in one context, security in another. ${ }^{72}$ For example, feminists might argue for the right to sexual freedom in the context of abortion, sodomy statutes, and statutory rape, and for the right to sexual security in the context of marital rape, pornography, and sexual harrassment. As between areas of the law, therefore, women are forced to take contradictory positions. A discourse of rights transforms the real issue of power into a liberal disagreement over "where social controls should end and sexual freedom should begin."73 Again, only the reality of sexual power relations can transform the niceties of linedrawing and the contradictory rhetoric of freedom and security into comprehensive, meaningful principles of sexual equality.

Finally, a rights challenge to the marital rape exemption reflects and reinforces the aggregate imbalance of power between men and women in society because it fails to identify marital rape as the systematic oppression of women by men. ${ }^{74} \mathrm{~A}$ rights approach individualizes the problem of marital rape by defining it in terms of individual rights. It identifies the evil to be corrected as the violation of individual rights, rather than the sexual subordination of one group in society to another. When courts affirm a woman's individual right to bodily security, they conjure an image of the solitary woman, safe in her bedroom. By individualizing the problem of subordination in this way, rights analysis fails to facilitate the creation of bonds among women that would serve to empower them as a group.

A rights approach to the marital rape exemption is limited because it abstracts away from the reality of power relations and conceives of social relations in terms of individual rights. For these reasons, it may not be the most desirable legal avenue by which to challenge the marital rape exemption. Part III of this Note provides an alternative approach - gender discrimination analysis - that conceptualizes the marital rape exemption in terms of collective power relations.

oF LAW (2d ed. 1977) (establishing a hierarchy of rights based on neutral principles of allocative efficiency); L. TRIBE, supra note 60, § II-4, at 572-75 (establishing a hierarchy based on "fundamental" rights inherent within liberal society); Wellington, Common Law Rules and Constitutional Double Standards: Some Notes on Adjudication, 83 YALE L.J. 221 (I973) (establishing a hierarchy derived from conventional morality).

72 See Olsen, supra note 69 , at $388-90$. "The central problem of the sexuality debate is that women are oppressed by moralistic controls society places on women's sexual expression, yet women are also oppressed by violence and sexual aggression that society allows in the name of sexual freedom." Id. at 388 .

${ }^{73} \mathrm{Id}$. at 389 .

${ }^{74} \mathrm{Cf}$. MacKinnon, supra note 3 , at 652 ("What is wrong with rape is that it is act of the subordination of women to men."). 


\section{The Gender Discrimination ApProach}

The marital rape exemption can be either gender-based or genderneutral, depending upon the language used to define rape. A rape statute that defines rape to exclude unconsented-to intercourse with "the wife" of the actor (a nonreform statute) is gender-based. A rape statute that defines rape to exclude unconsented-to intercourse with "the spouse" of the actor (a reform statute) is gender-neutral. Part III argues that both gender-based and gender-neutral marital rape exemptions discriminate against women in violation of the equal protection clause. Section A argues that in nonreform states with genderbased statutes, the exemption fails to withstand intermediate scrutiny under the equal protection clause. Section B argues that in reform states with gender-neutral statutes, the exemption masks intentional discrimination against women, rendering it invalid under Personnel Administrator v. Feeney. ${ }^{75}$

\section{A. Nonreform States}

In nonreform states, men are generally exempted from prosecution for the rape of their wives. The gender-based wording of the exemption is important because statutes that discriminate on the basis of gender fall subject to intermediate scrutiny under the equal protection clause. ${ }^{76}$ In a recent line of cases concerning pregnancy classifications, the Supreme Court has declined to recognize statutes as gender-based unless they distribute benefits and burdens in a purely gender-based fashion. ${ }^{77}$ In Geduldig $v$. Aiello, ${ }^{78}$ the Court held that a statute excluding pregnancy as a form of disability was not gender-based because, although the non-benefitted class (pregnant persons) consisted entirely of women, the benefitted class (nonpregnant persons) comprised both men and women. In contrast, however, the marital rape exemption burdens all women ${ }^{79}$ and benefits only men. It thus embraces a pure gender bias.

As noted above, a statute that classifies on the basis of gender is subject to intermediate scrutiny under the equal protection clause. ${ }^{80}$ Intermediate scrutiny requires that the challenged statutory classifi-

75442 U.S. 256 (1979).

${ }^{76}$ See City of Cleburne v. Cleburne Living Center, Io5 S. Ct. 3249, 3255 (I985).

77 See General Elec. Co. v. Gilbert, 429 U.S. I25, 135 (1976); Geduldig v. Aiello, 417 U.S. 484,497 n.20 (I974).

${ }^{78} 417$ U.S. 484 (1974). Criticizing the Court's holding that discrimination against pregnant people is not gender-based has become a "cottage industry." Law, supra note I8, at 983 \& n.107 (citing over two dozen law review articles condemning the Geduldig Court's approach and result).

${ }^{79}$ See supra p. 1264 (arguing that the marital rape exemption unconstitutionally burdens all women's right to privacy).

80 See City of Cleburne v. Cleburne Living Center, I05 S. Ct. 3249, 3255 (1985). 
cation be substantially related to important governmental objectives. ${ }^{81}$ In evaluating governmental objectives, "[c]are must be taken in ascertaining whether the statutory objective itself reflects archaic and stereotypic notions."82 As discussed below, the objectives behind the marital rape exemption reflect such notions; the exemption therefore fails to withstand intermediate scrutiny.

I. Fostering Marital Harmony and Intimacy. - The most compelling modern rationale behind the marital rape exemption is fostering marital harmony and intimacy by protecting the privacy of the marital relationship. ${ }^{83}$ This rationale, however, falsely assumes all marriages are true to the ideal conception of the harmonious and intimate nature of marital relations. Statistics such as those on marital violence undermine the legitimacy of this ideal. ${ }^{84}$ The state has no interest in preserving a deteriorated marriage, ${ }^{85}$ and marital rape is one of the strongest signs of such deterioration. Rape itself disintegrates the marriage; a wife's criminal complaint testifies to the absence of marital harmony and intimacy.

2. Encouraging Reconciliation of Spouses. - A second rationale advanced for the marital rape exemption is that of encouraging the reconciliation of the spouses. ${ }^{86}$ This rationale, however, also falls short under intermediate scrutiny. As one court noted, "it is the violent act of rape and not the subsequent attempt of the wife to seek protection through the criminal justice system which 'disrupts' a marriage." 87 In reality, reconciliation in the context of marital rape is often a stage in the cycle of psychological dependence upon a violent,

${ }^{81}$ See Heckler v. Mathews, 104 S. Ct. 1387, 1397-98 (1984) (quoting Mississippi Univ. for Women v. Hogan, 458 U.S. $718,724-25$ (I982)).

82 Mississippi Univ. for Women, 458 U.S. at 725.

83 See People v. Liberta, 64 N.Y.2d 152, I65, 474 N.E.2d 567, 574 (I984); cf. Griswold v. Connecticut, 38 I U.S. 479,486 ( 1965 ) (holding that the Constitution implicitly protects the right to marital privacy).

84 See M. Pagelow, Women-Battering: Victims and Their Experiences 99 (ig8I) (noting that $80.5 \%$ of all battered women are beaten by their husbands).

${ }^{85}$ See Trammel v. United States, 445 U.S. 40,52 ( 1980 ) (modifying the privilege against adverse spousal testimony because the willingness of one spouse to testify against the other suggests that there is "little in the way of marital harmony for the privilege to preserve"); Planned Parenthood v. Danforth, 428 U.S. 52, 7I (1976) ("No marriage may be viewed as harmonious or successful if the marriage partners are fundamentally divided on so important and vital an issue [as whether to terminate a pregnancy]."); Liberta, 64 N.Y.2d at 165,474 N.E.2d at 574 (holding that the right of marital privacy "protects consensual acts, not violent sexual assault").

${ }^{86}$ See Liberta, 64 N.Y.2d at I65, 474 N.E. at 574 ; see also Comment, supra note 14 , at 725 ("If reconciliation between married persons is to be encouraged, it would appear best to allow a husband to be prosecuted for rape only after absolute and final divorce.").

${ }^{87}$ People v. Liberta, 64 N.Y.2d 152, I65, 474 N.E.2d 567, 574 (1984) (citing Weishaupt v. Commonwealth, 227 Va. 389 , 397, 3r5 S.E.2d 847,855 (1984)). 
abusive husband. ${ }^{88}$ This rationale accepts the view that the harmful effects of marital rape are somehow mitigated by prior sexual acts, that intimacy serves to soften the blow. 89 By adhering to the notion that prior consent nullifies the brutality of rape, this view distorts the reality of such an experience for its victims.

3. Overcoming Evidentiary Difficulties. - A third rationale addresses the evidentiary difficulties in proving lack of consent in the prosecution of marital rape claims. This view, rooted in a fear that wives will threaten their husbands with fabricated rape claims to avenge personal wrongs or to extort large property settlements upon divorce, 90 reflects a profoundly discriminatory attitude towards women. The element of consent in rape is always difficult to prove. Yet it has never been suggested that the criminal offense of "stranger rape" be eliminated due to the difficulties of proof posed by a consent standard. 91

In addition, the evidentiary rationale ignores reality. There is no reason to believe that false charges of rape are brought more often than false charges of any other crime. ${ }^{92}$ In fact, women in general and wives in particular are deterred from bringing legitimate complaints of rape by the social stigma associated with such a charge. ${ }^{93}$ Our culture claims rape as a weapon in the power struggle between the sexes; women, socialized to feel ashamed of being raped, privatize the experience. They often conceal the fact that they have been raped in order to avoid a second, public victimization by friends, family, and the judicial system.

The rationales behind the marital rape exemption thus fail to constitute "important governmental objectives" under an intermediate standard of judicial review. Even were a court to overlook the discriminatory notions behind these rationales, the exemption is not directly and substantially related to those rationales. The state interests

88 This cycle is familiar to battered wives. See L. WALKer, The BatTered WoMan $47-$ 48 (1979).

89 See Comment, supra note 14 , at 724 ("In the ordinary marriage relationship] the parties have at times been very intimate, and the possibilities of serious social, physical or mental harm from a familiar, if unwanted, conjugal embrace are rather small.").

90 See Liberta, 64 N.Y.2d at $165-66,474$ N.E.2d at 574; Estrich, supra note 39; Comment, supra note $\mathrm{I}_{4}$, at 725 .

91 Rather than decriminalize the behavior, states should inquire into the continuing viability of the consent standard. See Estrich, supra note 39 (arguing that the purpose behind the consent rule is not to protect female autonomy and freedom of choice, but rather to assure men the broadest sexual access to women).

92 See People v. Liberta, 64 N.Y.2d. 152, I66, 474 N.E.2d 567, 574 (1984) ("[M]f the possibility of fabricated complaints were a basis for not criminalizing behavior which would otherwise be sanctioned, virtually all crimes other than homicides would go unpunished.").

93 See J. BODE, Fighting BACK II-I2 (1978) (noting that rape is one of the most underreported of violent crimes); D. RUSSELL, supra note 27 , at 303 (same). 
behind the marital rape exemption, although legitimate and important in other contexts, utterly fail in the context of marital rape. As a result, a gender-based marital rape exemption, as formulated in nonreform states, fails to withstand intermediate scrutiny.

\section{B. Reform States}

In Personnel Administrator v. Feeney, ${ }^{94}$ the Supreme Court announced a test for evaluating gender-neutral statutes that allegedly discriminate on the basis of sex. ${ }^{95}$ Feeney asks whether the facially neutral law reflects covert discriminatory intent. 96 Although a statute's adverse impact provides an "important starting point," "97 courts must look to legislative history as the primary evidence of intent. In reform states rape is defined to exclude the spouse of the actor, thereby rendering the exemption facially gender-neutral. In these states, therefore, the Feeney test would apply to the exemption. This Section argues that the adverse effects and legislative history of the marital rape exemption reveal discriminatory intent, thus rendering the exemption unconstitutional.

I. Adverse Impact. - Part I examined the many adverse effects of the marital rape exemption upon married women raped by their husbands. ${ }^{98}$ In addition to the immediate, personal harm caused by marital rape, women in general suffer harm in two different ways. First, the exemption indirectly affects the entire class of women by sanctioning sexual violence against women. By permitting marital rape, the law helps to perpetuate a myth of the powerless, subordinate female. The marital rape exemption serves to legitimate rape as passion, contributing to the eroticization of violence against women in our culture.

Second, the marital rape exemption perpetuates "archaic and overbroad" generalizations concerning the proper roles of the sexes. ${ }^{99}$ At worst, these generalizations portray women as the property of their husbands or as naturally bound to provide them with sexual services.

${ }^{94} 44^{2}$ U.S. 256 (1979).

95 The Feeney Court developed its test in the course of inquiring whether Massachusetts, in granting an absolute lifetime hiring preference to veterans, had discriminated against women in violation of the equal protection clause. See id. at $27 \mathrm{I}$.

96 See id. An intent-oriented analysis had already been applied to cases involving racial discrimination. See, e.g., Village of Arlington Heights v. Metropolitan Hous. Dev. Corp., 429 U.S. 252, 265-68 (1977); Washington v. Davis, 426 U.S. 229, 24I-45 (1976).

${ }^{97}$ Feeney, 442 U.S. at 274 (quoting Arlington Heights, 429 U.S. at 266).

98 See supra pp. 126I-62.

${ }^{99}$ Schlesinger v. Ballard, 4 I9 U.S. $498,507-08$ (1975) (upholding a statute that mandated differential treatment for male and female naval officers, but suggesting that statutes perpetuating discriminatory stereotypes would be invalid). 
At best, they help perpetuate the ideology of separate spheres. ${ }^{100}$ The Supreme Court in recent years has made clear that laws promoting debilitating gender stereotypes must be subject to heightened scrutiny because they freeze biology into social destiny. ${ }^{101}$ The Court has appeared most willing to recognize gender discrimination where the law in question discouraged or prevented departure from traditional sex roles. The marital rape exemption "freezes" women in the role of sexual objects for their husbands' pleasure.

2. Discriminatory Legislative Intent. - The Court has held that "purposeful discrimination is the condition that offends the Constitution." 102 In Feeney, the Court stated that the existence of discriminatory purpose means that the decisionmaker "selected or reaffirmed a particular course of action at least in part 'because of,' not merely 'in spite of,' its adverse effects upon an identifiable group."103 The primary evidence of discriminatory purpose derives from the historical background and legislative history of a law. Feeney requires a showing that the legislature adopted the law at least in part "because of" its adverse effects upon women.

In its recent decision in Hunter $v$. Underwood, ${ }^{104}$ the Supreme Court noted that "[p]roving the motivation behind official action is often a problematic undertaking." 105 To discern the legislative motive behind a racially neutral constitutional provision with a racially disproportionate impact, ${ }^{106}$ the Court in Hunter relied upon the proceedings of the constitutional convention, historical studies, and the testimony of historians. ${ }^{107}$ Unfortunately, legislative records of the adoption of marital rape exemptions are not available; nineteenthcentury committee reports, debates, and hearings rarely exist at the state level. 108 However, judicial opinions and treatises from that

${ }^{100} C f$. City of Cleburne v. Cleburne Living Center, I05 S. Ct. 3249, 3255 (Ig85) ("Rather than resting on meaningful considerations, statutes distributing benefits and burdens between the sexes in different ways very likely reflect outmoded notions of the relative capabilities of men and women.").

101 See L. TRIBE, supra note $60, \S \mathrm{I6-25}$, at 1065.

102 Personnel Admr. v. Feeney, 442 U.S. 256, 274 (1979) (quoting Swann v. CharlotteMecklenburg Bd. of Educ., 402 U.S. I, I6 (I97I)).

103 Id. at 279.

104 I05 S. Ct. I9I6 (I985).

105 Id. at 1920 .

106 The Court found in Hunter that a state constitutional provision that disenfranchised persons convicted of crimes involving moral turpitude had a racially discriminatory impact. See id. at 1920 .

${ }^{107} \mathrm{See}$ id. at 1920-22. In Michael M. v. Superior Court, 450 U.S. 464 (1980), the Court did not have evidence of the legislative proceedings as a basis for establishing legislative motivation. The Court posed the question of motivation as follows: "[The State's asserted reason for the enactment of a] statute may be rejected, if it 'could not have been a goal of the legislation." Id. at 470 (quoting Weinberger v. Wiesenfeld, 420 U.S. 636,648 n. I6 (I975)).

108 See R. Carter, Legislative INTENT IN New York STate I (I98I). 
period confirm that the marital rape exemption was codified from the common law on the basis of Hale's declaration that a woman gives her irrevocable consent to sexual intercourse upon marriage. ${ }^{109}$ This implied consent theory reflects a discriminatory vision of women as property and as naturally destined for life in the private sphere. The discriminatory purpose underlying this theory constituted the but-for motivation for the exemption at the time of its adoption and served as the exemption's primary rationale well into the twentieth century. 110

Notwithstanding the discriminatory legislative intent behind the marital rape exemption, proponents of the exemption argue that contemporary rationales satisfy intermediate scrutiny. The Hunter Court, however, held that contemporary justifications can never supersede an historically discriminatory purpose when that purpose constitutes the but-for motivation. ${ }^{111}$ In any case, the contemporary justifications for the marital rape exemption, although different in form from their nineteenth-century predecessors, continue to reflect an underlying adherence to an ideology of female inferiority. ${ }^{112}$ Modern rationales have their roots in the notion of women as chattel and as unfit for life in the public sphere. Preserving marital privacy, encouraging reconciliation, and obviating evidentiary difficulties are modern formulae for the same nineteenth-century potion - women's subordination. Because these rationales fail to overcome an intermediate level of judicial review, the exemption must be held unconstitutional.

\section{CONCLUSION}

Rights analysis and gender discrimination law can effectively be used to broaden legal perspectives so as to incorporate women's ex-

${ }^{109}$ See State v. Haines, 25 So. 372, 372 (La. 1899) (holding that a husband was not guilty of marital rape because "of the matrimonial consent which [the wife] has given, and which she cannot retract"); People v. Liberta, 64 N.Y.2d 152, I63, 474 N.E.2d 567, 572 (I984) (noting that late nineteenth-century courts adopted the marital rape exemption "usually with no rationale or authority cited other than Hale's implied consent view"); J. Bishop, 2 Treatise on Criminal LAW 828 (1892) ("[A husband] does not on account of the matrimonial consent which cannot be retracted become guilty of rape by forcing his wife to his own embraces.").

The absence of records from the legislative proceedings need not render the inquiry into legislative motive futile. Professor C. Edwin Baker argues that "[a]lthough the Court often uses the language of subjective intent, its opinions can be best understood as treating objective or contextual purpose as the key constitutional concern." Baker, Outcome Equality or Equality of Respect: The Substantive Content of Equal Protection, I3I U. PA. L. REv. 933, 976-77 (1983); see also Personnel Admr. v. Feeney, 442 U.S. 256, 283 (I979) (Marshall, J., dissenting) ("[S]ince reliable evidence of subjective intentions is seldom obtainable, resort to inference based on objective factors is generally unavoidable.").

${ }^{110}$ See, e.g., People v. Meli, 193 N.Y.S. 365,366 (1922) ("[T]he husband of a woman cannot himself be guilty of an actual rape upon his wife, on account of the matrimonial consent which she has given, and which she cannot retract.").

111 See Hunter v. Underwood, 105 S. Ct. I916, 1923 (1985).

112 See supra pp. 1268-69. 
perience. There is a danger, however, in viewing legal victories as ends in themselves, rather than as means by which to inspire collective social movements. Legal gains can effectively be used to destabilize existing inequalities of power so long as these victories are perceived in terms of their broader political impact. In the area of gender equality, for example, the available legal tools, most notably the fourteenth amendment, work well to dismantle intentional, blatant forms of discrimination. Deeper, more institutional forms of discrimination, however, remain immune to conventional legal analysis, ${ }^{113}$ leaving unaltered the traditional imbalance of power between men and women. ${ }^{114}$ Although inadequate as a comprehensive strategy for systemic change, these tools nevertheless can attack the points at which power influences the daily lives of men and women. By challenging these points of impact, of which marital rape is one, the legal system takes a step toward equality of power between men and women.

The rights and gender discrimination approaches present alternative ways for taking that step. As a practical matter, the rights approach offers a solid, straightforward legal argument with no digressions into the meaning of gender-neutrality or legislative intent. Although arguably a more tenuous legal argument, the gender discrimination approach offers benefits beyond the specific context of marital rape. By focusing upon the harm done to women as a group, and by identifying the issue as inequality, the gender discrimination approach forces courts to focus upon the reality of collective power relations. Whereas rights analysis recognizes the pain that women suffer alone in their bedrooms, gender discrimination analysis recognizes the pain they share.

113 The Supreme Court's approach to gender discrimination under the equal protection clause reflects the view that "natural" or "real" differences between men and women justify differential treatment, see, e.g., Michael M. v. Superior Court, 450 U.S. 464, 47I (198I) (holding a pregnancy-based classification to be gender-neutral); Personnel Adm'r v. Feeney, 442 U.S. 256, 274-75 (1979) (holding that the state's hiring preference for veterans "excludes significant numbers of women from preferred state jobs [not] because they are women [but] because they are nonveterans"). See generally Freedman, Sex Equality, Sex Differences, and the Supreme Court, 92 YALE L.J. 9I3 (Ig83) (arguing that the Supreme Court's approach to sex discrimination under the equal protection clause simultaneously acknowledges and denies the need for significant changes in sex roles and sex-based hierarchy).

114 Two areas where the law has failed to remedy systemic discrimination are pregnancy disability, see, e.g., Geduldig v. Aiello, 4I7 U.S. 484, 497 (I974) (holding that a law excluding pregnancy from a disability insurance system did not discriminate against women), and discrimination in compensation (i.e., comparable worth), see, e.g., AFSCME v. Washington, 770 F.2d I40I, I 408 (9th Cir. 1985) (holding that the state's decision to base compensation on a market system that systematically devalued jobs traditionally held by women was not enough to establish liability under title VII). 